УДК 37.017

DOI https://doi.org/10.52726/as.pedagogy/2021.3.2.3

\author{
М. I. ГАГАРIH \\ доктор педагогічних наук, дочент, \\ доиент кафедри педагогіки та освітнього менеджменту, \\ Уманський державний педагогічний університет імені Павла Тичини, \\ м. Умань, Черкаська область, Україна \\ Електронна пошта: mikolagagarin0@gmail.com \\ http://orcid.org/0000-0002-4773-3303
}

\title{
ПРОГРАМА ОЦНЮЮАННЯ ЕФЕКТИВНОСТІ ВИХОВНОЇ СИСТЕМИ ЗАКЛАДУ ЗАГАЛЬНОЇ СЕРЕДНЬОЇ ОСВІТИ
}

У статті здійснено аналіз сучасної виховної ситуації у закладах загальної середньої освіти. Метою статті є визначення й обгрунтування програми оцінювання ефективності виховної системи закладу загальної середньої освіти. Висвітлено сутність поняття «виховна система», «гуманістична виховна система».

Виховну систему закладу загальної середньої освіти визначено як комплекс взаємопов'язаних і взаємозумовлених основних компонентів (таких як виховна мета, концепція, завдання, суб’єкти (учні, педагогічні працівники, батьки), виховне середовище), що становить цілісну соціально-педагогічну структуру і забезпечує у процесі свого функціонування та розвитку становлення, реалізацію та самореалізацію особистості, іiі життєздійснення у соціальній, фізичній, психічній і духовній сферах. Визначено чинники, які впливають на функціонування виховної системи конкретного закладу освіти (систему цінностей, структуру та життєдіяльність закладу освіти; соціальнопсихологічний клімат, організаційну культуру, кадровий потенціал, особливості контингенту учнів; забезпеченість ресурсами; вплив зовнішнього середовища та ін.).

Робиться висновок, що феномен виховної системи є складним і багатомірним явищем, а створення сучасних виховних систем у закладах загальної середньої освіти - потреба часу. Наголошується на необхідності створення гуманістичних виховних систем, які спрямовані на розвиток особистості учня та базуються на індивідуальному особистісно зорієнтованому підході. Програма оцінювання виховної системи закладу загальної середньої освіти базується на таких критеріях, як самодостатність, цілісність, універсальність, стійкість, результативність.

Матеріали дослідження можуть бути використані у процесі оцінювання виховного процесу у сучасних закладах загальної середньої освіти. Подальших досліджень потребує вивчення вітчизняного та зарубіжного досвіду щодо цієї проблематики.

Ключові слова: виховна система закладу загальної середньої освіти, програма оцінювання ефективності виховних систем, стійкість, самодостатність, цілісність, універсальність, результативність.

Поставлення проблеми До дієвих шляхів розв'язання проблем виховання особистості належить створення та функціонування виховних систем у закладах освіти. Як справедливо зазначає В. Оржехівська, сучасний заклад освіти «згинається» під тягарем дидактики. На виховну діяльність, роботу з батьками часу не залишається [Оржехівська : 21]. Саме тому виховний процес у сучасній школі здійснюється переважно узагальнено та стихійно, не $\epsilon$ достатньо регульованим. Організація та здійснення освітнього процесу в закладах загальної середньої освіти ускладнюється низкою карантинних обмежень, зумовлених пандемією Covid-19.

Автори програми «Нова українська школа» у поступі до цінностей наголошують, що потребує вирішення проблема забезпечення сис- темності та цілісності в організації виховання учнів у закладах освіти [Програма].

3 огляду на різноманіття закладів освіти, побудови виховних систем, специфіку організації виховної діяльності необхідно здійснити дослідження проблеми аналізу й оцінювання ефективності виховних систем.

Аналіз попередніх досліджень. Наукові засади становлення, розвитку виховних систем закладів освіти обгрунтовано у працях В. Кабуша, В. Караковського, Л. Новикової, Г. Сороки та ін.

Особливості освітньої діяльності педагогів за сучасних умов стали предметом дослідження О. Кравченко, М. Міщенко, О. Сафіна та ін. Аналіз ефективності функціонування виховних систем здійснили О. Гречаник, I. Срмаков, В. Караковський, Л. Новикова та ін. Однак 
потребує дослідження проблема створення програми оцінювання виховної системи, що може бути використана у різноманітних закладах освіти.

Мета статті полягає у визначенні й обгрунтуванні програми оцінювання ефективності виховної системи закладу загальної середньої освіти.

Виклад основного матеріалу. Виховну систему закладу загальної середньої освіти визначаємо як комплекс взаємопов'язаних і взаємозумовлених основних компонентів (таких як виховна мета, концепція, завдання, суб'єкти (учні, педагогічні працівники, батьки), виховне середовище), що становить цілісну соціальнопедагогічну структуру і забезпечує у процесі свого функціонування та розвитку становлення, реалізацію і самореалізацію особистості, іiі життєздійснення у соціальній, фізичній, психічній і духовній сферах.

Найбільш ефективними $є$ гуманістичні виховні системи, які характеризуються ставленням до особистості як до найвищої цінності на емоційно-афективному, раціональному рівнях і водночас передбачають індивідуальний особистісно зорієнтований підхід до учня.

До чинників, що визначають особливості функціонування виховної системи конкретного закладу освіти, належать система цінностей закладу загальної середньої освіти, його структура та життєдіяльність; соціально-психологічний клімат, організаційна культура, кадровий потенціал, особливості контингенту учнів; забезпеченість ресурсами; вплив зовнішнього середовища та ін.

Оцінювання ефективності виховних систем закладів освіти може здійснюватися на основі програми аналізу стану виховної системи за визначеними нами критеріями (стійкістю, самодостатністю, цілісністю, універсальністю, результативністю) відповідно до таких позицій, як:

I. Узагальнені дані про заклад загальної середньої освіти:

- офіційна назва закладу освіти, статус (опорний заклад, філія та ін.), тип (школа, гімназія, ліцей, коледж, спеціальна школа, навчально-реабілітаційний центр, школа-інтернат, авторська школа, школа-комплекс, експериментальний майданчик, ліцей (спортивний мистецький, військовий та ін.); організаційно- правова форма (державний, комунальний, приватний, корпоративний); територіальна належність (найменування адміністративнотериторіальної одиниці за місцезнаходженням закладу освіти); наявність профільних класів, внутрішніх структурних підрозділів: дошкільний (у складі початкової школи або гімназії); позашкільний; пансіон (у складі ліцеїв, закладів спеціальної освіти та закладів інтернатного типу); інші внутрішні структурні підрозділи; наявність філії (філій), класів (груп) із навчанням мовою корінного народу або національної меншини);

- мікрорайон закладу загальної середньої освіти, його найближче оточення: соціальний i етнічний склад сімей, які переважають професії та заняття батьків, джерела позитивного і негативного впливу, молодіжне середовище, статус закладу серед населення;

- кількісні характеристики (кількість учнів, класів, груп продовженого дня, факультативів, гуртків, спортивних секцій; кадрове забезпечення закладу освіти);

- прізвище, ім'я, по батькові директора, заступників, інших представників адміністрації; поштова адреса закладу освіти, номер телефону, факс, електронна пошта.

II. Цілісність виховної системи:

- концепція виховної системи (сукупність ідей, що лежать в основі виховної системи);

- гуманістичні цілі виховної системи, особливості процесу цілепокладання; участь у цьому процесі вчителів, учнів, батьків, представників громадськості;

- наявність системоутворюючої діяльності, яка реалізує цільову установку системи, інші пріоритетні види діяльності, найбільш часто використовувані форми їх організації;

- створення та функціонування виховного середовища;

- відносини між суб'єктами виховної системи (учні та педагоги, педагоги та батьки, педагоги й адміністрація);

- наявність почуття шкільної спільноти та форми його прояву;

- наявність різних об'єднань, організацій, рухів (постійних і тимчасових) учнів, вчителів, батьків; зміст і форми їх взаємодії;

- управління виховною системою (органи, методи, форми управління); 
- самоврядування (органи самоврядування, діяльність учнів, педагогів, батьків, представників громадськості).

III. Самодостатність виховної системи:

- своєрідність і специфіка, унікальність, єдність загального й особливого, притаманного системі (умови, інновації, традиції, рівень вихованості учнів, склад і потенціал педагогічного колективу, середовище та ін.);

- створення та функціонування виховної системи з урахуванням особливостей середовища (природного, предметного, соціокультурного та ін.), регіональних, національних, демографічних особливостей тощо;

- ознаки гуманістичної спрямованості виховної системи та іï особливості;

- цінності, що об'єднують суб'єктів виховної системи (учні, педагоги, батьки);

- культура виховної системи (традиції, інновації, ритуали, норми шкільного життя, їх знання і виконання; символи, сленг та ін.).

IV. Стійкість виховної системи:

- позиція педагога як вихователя щодо учнів, інших учасників виховної системи;

- можливості власного саморозвитку;

- взаєморозуміння та підтримка педагогічного колективу;

- подолання негативних впливів середовища, що оточує виховну систему школи;

- використання виховних можливостей середовища, участь учнів, батьків у його перетворенні, вдосконаленні;

- взаємодія з іншими школами, $з$ дошкільними, позашкільними, культурно-освітніми закладами, їх колективами та ін., зміст і форми взаємодії;

- перевірка часом (міцність зв'язку поколінь, традиції, колективні звички).

- інтеграційні процеси (створення різноманітних форм інтеграції: «ключових справ», виховних центрів, комплексів, клубів та ін.; взаємопроникнення навчання і виховання; зв'язки між ровесниками й учасниками виховної системи різного віку);

V. Універсальність виховної системи:

- психолого-педагогічне забезпечення діяльності виховної системи.

- здійснення фізично-оздоровчої, оцінювально-орієнтаційної, предметно-перетворювальної, соціально-комунікативної, навчально- пізнавальної та ін. діяльності за умов виховної системи.

Процес розвитку виховної системи:

- суперечності у розвитку виховної системи;

- невикористані резерви розвитку виховної системи;

- перспективи розвитку виховної системи;

- найбільш оригінальні знахідки у житті закладу освіти.

Науково-дослідницька діяльність у межах виховної системи:

- дослідницька проблема, над якою працює педагогічний колектив закладу освіти;

- участь педагогічного колективу (окремих вчителів) у дослідженні проблематики виховання особистості, моделювання, проєктування та розвитку виховних систем.

VI. Результативність виховної системи.

Якісні показники ефективності функціонування виховної системи З3СО:

- образ закладу освіти у свідомості педагогів, учнів, представників громадськості, батьків;

- образ випускника як ідеальний результат функціонування виховної системи;

- психологічний клімат. Самопочуття учнів, педагогів у школі;

- ставлення до внутрішньошкільних конфліктів;

- характер відносин між різними суб'єктами системи;

- співбуття як характеристика діяльності;

- авторитет школи (ставлення до школи працівників органів управління освітою, батьків, учнів, жителів).

Опрацювання результатів передбачає оцінювання у балах зазначених показників одночасно або поетапно:

- «0» балів виставляється тоді, коли показник не виявляється взагалі;

- «1» бал виставляється, якщо показник виявляється епізодично або частково;

- «2» бали виставляється, якщо показник виявляється досить часто та чітко;

- «3» бали виставляється, якщо показник виявляється постійно та чітко.

Коефіціснт ефективності функціонування виховної системи вимірюється за формулою «фактична кількість балів поділена на максимально можливу кількість балів». Оптимальним $€$ рівень коефіцієнту від «0,8» і вище. 
Зазначимо, що використання програми оцінювання виховної системи $33 \mathrm{CO}$ сприятиме отриманню достовірної інформації, вибору шляхів подальшого розвитку виховної системи.

Висновки. Отже, з'ясовано особливості оцінювання виховної системи закладу загальної середньої освіти й обгрунтовано програму аналізу стану виховної системи, яка базується на виокремлених критеріях ефективності виховної системи закладу загальної середньої освіти, таких як самодостатність, цілісність, універсальність, стійкість, результативність.

Стаття не вичерпує всіх аспектів порушеної проблеми. До перспективних напрямів належить, зокрема, аналіз вітчизняного та зарубіжного досвіду щодо удосконалення виховної діяльності у закладах освіти.

\section{ЛІТЕРАТУРА}

1. Виховна система загальноосвітнього навчального закладу: контури розвитку : посібник / за ред. В. М. Оржеховська. Тернопіль : Терно-граф, 2013. 304 с.

2. Виховні системи навчальних закладів: теорія та практика / уклад. О. С. Гречаник. Харків : Основа, 2014. 224 с.

3. Кабуш В. Т. Гуманистическая воспитательная система: теория и практика. Минск : Академия последипломного образования, 2001. $332 \mathrm{c}$.

4. Новикова Л. И. Воспитание как педагогическая категория. Педагогика. 2000. № 6. С. 32-33.

5. Програма «Нова українська школа» у поступі до цінностей. Київ, 2018. 40 с.

6. Сорока Г. І. Сучасні виховні системи та технології : посібник. Харків, 2002. 128 с.

7. Safin O., Kravchenko O., Mishchenko M., Potapchuk Y. Peculiarities of Psychologists' and Social Pedagogues' Work in Terms of Quarantine. Lecture Notes in Networks and Systems. 2021. V. 267. P. 149-157.

\section{REFERENCES}

1. Vykhovna systema zahalnoosvitnoho navchalnoho zakladu: kontury rozvytku [The educational system of a secondary school: the contours of development]. V. M. Orzhekhovska. (Ed.) (2013). Ternopil: Terno-hraf, 304 p. [in Ukrainian].

2. Vykhovni systemy navchalnykh zakladiv: teoriia ta praktyka [Educational systems of educational institutions: theory and practice]. O. Ye. Hrechanyk (Ed.) (2014). Kharkiv: Osnova. 224 p. [in Ukrainian].

3. Kabush, V. T. (2001). Gumanisticheskaja vospitatelnaja sistema: teorija i praktika [The humanistic educational system: theory and practice]. Minsk: Academy of Postgraduate Education. 332 p. [in Russian].

4. Novikova, L. I. (2000). Vospitanie kak pedagogicheskaja kategorija [Education as a pedagogical category]. Pedagogy. issue 6, p. 32-33 [in Russian].

5. Prohrama "Nova ukrainska shkola" u postupi do tsinnostei [The New Ukrainian School program is in the process of moving towards values] (2018). Kyiv. 40 p. [in Ukrainian].

6. Soroka, H. I. (2002). Suchasni vykhovni systemy ta tekhnolohii: posibnyk [Modern educational systems and technologies: a guide]. Xarkiv, 128 p. [in Ukrainian].

7. Safin, O., Kravchenko, O., Mishchenko, M., Potapchuk, Y. (2021) Peculiarities of Psychologists' and Social Pedagogues' Work in Terms of Quarantine. Lecture Notes in Networks and Systems. 2021. V. 267. P. 149-157.

\section{I. GAGARIN}

Doctor of Pedagogical Sciences, Associate Professor,

Associate Professor at the Department of Pedagogy and Education Management,

Pavlo Tychyna Uman State Pedagogical University,

Uman, Cherkasy region, Ukraine

E-mail:mikolagagarin0@gmail.com

http://orcid.org/0000-0002-4773-3303

\section{PROGRAM FOR EVALUATION OF THE EFFICIENCY OF THE EDUCATIONAL SYSTEM OF THE INSTITUTION OF GENERAL SECONDARY EDUCATION}

The article analyzes the current educational situation in general secondary education. The purpose of the article is to define and substantiate the program of evaluating the effectiveness of the educational system of general secondary education. The article covers the essence of the concept of "educational system", "humanistic educational system". 
The educational system of a general secondary education institution is defined as a complex of interrelated and interdependent basic components (educational goal, concept, tasks, subjects (pupils, teachers, parents), living space (system-forming activity, communication, relations, management, self-government, interaction), which is a complete socio-pedagogical structure and provides in the process of its functioning and development of formation, realization and self-realization of the individual, his life realization in the physical, mental, social and spiritual spheres. Factors influencing the functioning of the educational system of a particular educational institution (value system, structure and life of the educational institution; socio-psychological climate, organizational culture, human resources, features of the student body; provision of resources; environmental impact, etc.) are identified.

It is concluded that the phenomenon of the educational system is a complex and multidimensional phenomenon and the creation of modern educational systems in general secondary education is a matter of time. Emphasis is placed on the need to create humanistic educational systems aimed at developing the student's personality and based on an individual personality-oriented approach. The program of evaluation of the educational system of general secondary education is based on the following criteria: self-sufficiency, integrity, universality, stability, effectiveness.

Research materials can be used in the process of evaluating the educational process in modern institutions of general secondary education. Further studies require a study of domestic and foreign experience in this area.

Key words: educational system of general secondary education institution, program for evaluating the effectiveness of educational systems, stability, self-sufficiency, integrity, universality, effectiveness. 